\title{
Efficacy of Pegylated Interferon And Ribavirin Treatment In Coinfected HIV HCV Patients
}

${ }^{1}$ University "Ovidius" of Constanța, Faculty of Medicine, Infectious Diseases Clinic

${ }^{2}$ University "Ovidius" of Constanța, Faculty of Medicine, Gastroenterology Department

${ }^{3}$ University "Ovidius" of Constanţa, Faculty of Medicin, Nephrology Clinic

${ }^{4}$ University "Ovidius" of Constanţa, Faculty of Medicine, Infectious Diseases Clinic, AOSR (Academy scientists Romania)

\begin{abstract}
The objectives of the study were to determine the efficacy of pegylated interferon alfa $2 \mathrm{~b}$ (PegINF) and ribavirin (RBV) treatment in co-infected HIV / HCV patients, to identify predictive factors associated with sustained viral response (SVR) in these patients. Out of the 956 HIV infected patients, 38 were HCVAb (4\%) positive, 14 of which had undetectable HCV RNA, only 6 patients met the inclusion criteria. Screening failure was due to: liver cirrhosis Child Pugh B / C, hepatocellular carcinoma, pulmonary TB, thyroid dysfunction, CD4 $<200$ cells $/ \mathrm{mm} 3$, detectable HIV RNA and depressive syndrome. We initiated PegINF and RBV therapy for 48 weeks. SVR was achieved in $16.6 \%$ of cases (only one patient) and correlated with HCV RNA level, CD4 count, duration of HIV infection, $\mathrm{CDC}$ classification and liver fibrosis. In conclusion, our study group has a low prevalence of HIV / HCV co-infection $(2.6 \%)$ with a large number of patients HCVAb positive but undetectable HCV RNA. Positive predictive factors for SVR were: low levels of HCV RNA, small duration of HIV infection, high levels of $\mathrm{CD} 4, \mathrm{~B} 1 / \mathrm{B} 2$ (CDC classification) and low degree of fibrosis.
\end{abstract}

Keywords: HIV/ HCV coinfection, antiviral treatment, SVR

Eugen Dumitru

Blv Tomis no. 145, Department of Internal Medicine, County Emergency Clinical Hospital of Constanta, Constanta, Romania

email : eugen.dumitru@yahoo.com

\section{Introduction}

The morbidity and mortality caused by HCV in HIV infected patients has increased since the inception of highly active antiretroviral therapy (HAART) because HIV patients are living longer from antiretroviral therapies and prophylaxis of opportunistic infections. Liver disease has become a significant cause of death in patients with HIV in the era of HAART $[1,3,4,9]$. A meta-analysis of eight studies investigating the role of HIV on liver disease in $\mathrm{HCV}$-infected patients found that $\mathrm{HIV} / \mathrm{HCV}$ coinfected patients had approximately two times the risk of cirrhosis and approximately six times the risk of decompensated liver disease when compared to HCV-monoinfected patients [6]. Factors associated with mortality were older age, low CD4 cell counts and detectable plasma HIV-RNA [14].

Concurrent treatment of HIV and HCV is feasible but may be complicated by high pill burden, drug interactions and overlapping drug toxicities. If treatment with PegIFN/RBV is initiated, the ART regimen may need to be modified to reduce the potential for drug interactions and/or toxicities that may develop during the period of concurrent HIV and $\mathrm{HCV}$ treatment. [7,11]. ddI should not be given with RBV because of the potential drug-drug interactions leading to life-threatening situations (mitochondrial toxicity including liver toxicity, pancreatitis and lactic acidosis) [5]. Combined use of zidovudine 
(ZDV) and RBV is associated with a higher rate of anemia [2]. Abacavir (ABC) has been associated with decreased response to PegIFN/RBV $[8,13,15]$

\section{Objectives}

The primary objective was to determine the efficacy of pegylated interferon alfa $2 \mathrm{~b}$ and ribavirin treatment in co-infected HIV / HCV patients. The secondary objective: identifying predictive factors associated with sustained viral response (SVR) in these patients.

\section{Material and method}

Prospective study on 38 co-infected HIV / $\mathrm{HCV}$ patients in evidence at the HIV Clinical Center of Excellence Constanta, Romania.

This study was approved by the Ethical Committee of the Clinical Infectious Diseases Hospital Constanta and was carried in accordance with standard operation procedures ensuring Good Clinical Practice Guidlines. Written informed consent was obtained from all the subjects before admission to the study. Patients were evaluated biologically (CD4, VL, HCVAb, HCV RNA, alphafetoprotein, thyroid hormones), psychologically, ultrasound and FibroScan wise.

All eligible patients will be randomized to receive HAART associated with anti-HCV therapy (PegInterferon alfa $2 \mathrm{~b}$ and Ribavirin) for 6 or 12 months. We tested HCV-RNA at the 4 weeks, 12, 24, 48 and 72 weeks mark. We considered viral failure at the 12 week mark if HCV-RNA did not decrease by more than $10 \mathrm{log}$ and if HCV-RNA was detectable at the 24 week, 48 week or 72 weeks mark.

Inclusion Criteria: Age between 18-65 years old, subject has given written informed consent, confirmed diagnosis of HIV and HCV infection, naive for HCV-infection treatment, chronic hepatitis and/or compensated cirrhosis (Child class A), CD4+ count greater than 350 cells/mmc, HIV-RNA undetectable during the previous six month, stable HAART for more than 6 months, subject has genotype available at baseline and no mutations associated with resistance to PI or no viral failure on PI treatment, defined as a confirmed HIV-RNA level $>50 \mathrm{cp} / \mathrm{mL}$ after 24 weeks, $>50 \mathrm{cp} / \mathrm{ml}$ after 48 weeks, or a repeated HIV RNA level $>50 \mathrm{cp} / \mathrm{mL}$ after prior suppression of viremia to $<50 \mathrm{cps} / \mathrm{mL}$, free of any clinically significant disease (other than HIV and $\mathrm{HCV}$ ) that would interfere with study evaluations, subject will use effective contraceptive methods for the duration of the study

Exclusion Criteria: Positive for $\mathrm{Hbs} \mathrm{Ag}$, cirrhosis score Child-Pugh $\mathrm{B} / \mathrm{C}$, no previous hepatic decompensation, HIV-related thrombocytopenia (Platelets count $<50.000 / \mathrm{mmc}$ ), Neutrophils count $<1500 / \mathrm{mmc}, \mathrm{Hb}$ value $<11 \mathrm{~g} / \mathrm{dL}$, Creatinine value $>1.5 \mathrm{mg} / \mathrm{dL}$, Pregnant or wishes to become so, subject has any cause of liver disease other than chronic hepatitis $\mathrm{C}$, status of liver decompensation or any other condition consistent with decompensated liver disease (bleeding from esophageal varices, signs of current bleeding, significant ascites, hepatic encephalopathy), alcohol abuser (> $30 \mathrm{gr} / \mathrm{die}$ ), autoimmune hepatitis, prior treatment with PEG-IFN or ribavirin, illicit drug abuse that in the opinion of the investigator could lead to poor compliance with the terms of the protocol, active heart disease (e.g. angina, congestive heart failure, recent myocardial infarction or significant arrhythmia), pre-existing severe depression, condition of severe psychiatric disorders such as suicidal ideation, suicide attempts, depression or acute psychosis, uncompensated diabetes, active opportunistic infections or major opportunistic infections during the previous 12 months, intrahepatic tumor or other malignancy, known hypersensitivity or contraindication to study medications, any other condition that in the opinion of the investigator will make the subject unsuitable for enrolment or will interfere with the subject participating in or completing the study.

The first 6 months of therapy with peginterferon 
alfa- $2 b$ and ribavirin were offered within a project sponsorship, the next 6 months were sponsored for only 3 patients by the National Health Insurance.

\section{Results}

Out of the $956 \mathrm{HIV}$ infected patients in evidence at the HIV Center of Excellence Constanta, 38 were HCVAb (4\%) positive. Out of these, 14 patients had undetectable HCV RNA which means a truly low prevalence $(2.5 \%)$ compared to the non HIV patients in our region $(5 \%)$.

In the group of patients with detectable $\mathrm{HCV}$ RNA (24 cases) only 6 patients met inclusion criteria/ exclusion criteria.

Screening failure was due to: liver cirrhosis Child Pugh B / C (2 patients), hepatocellular carcinoma (1 case), pulmonary TB (1 case), thyroid dysfunction ( 2 patients), CD4 $<200 \mathrm{cel} / \mathrm{mm}^{3}$ (4 patients), detectable HIV RNA(6 patients), depressive disorders ( 2 cases), unwillingness to participate (5 cases).

We initiated peginterferon alfa $2 \mathrm{~b}$ and ribavirin therapy for 12 weeks in three cases (null responders), for 24 weeks in one case (partial responder) and 48 weeks in three other cases (two relapsers and one responder, with SVR at 72 and 96 weeks). See Table 1, Table 2
Table 1. Caracteristics of the HIV/HCV infected patients included in study

\begin{tabular}{|c|c|c|}
\hline & $\begin{array}{l}\text { HCV-RNA } \\
\text { 48wks } \\
\text { positive }\end{array}$ & $\begin{array}{l}\text { HCV-RNA } \\
48 \text { wks } \\
\text { negative }\end{array}$ \\
\hline All [No. (\%)] & $3(50)$ & $3(50)$ \\
\hline $\begin{array}{l}\text { Gender }[\text { No. }(\%)] \\
\text { Male } \\
\text { Female }\end{array}$ & $\begin{array}{c}0 \\
3(50) \\
\end{array}$ & $\begin{array}{c}0 \\
3(50) \\
\end{array}$ \\
\hline $\begin{array}{l}\text { Exposure group [No. } \\
(\%)] \\
\text { Vertical } \\
\text { Nosocomial } \\
\text { Heterosexual }\end{array}$ & $\begin{array}{l}0 \\
0 \\
3(50)\end{array}$ & $\begin{array}{l}1(16.6) \\
2(33.3) \\
0\end{array}$ \\
\hline $\begin{array}{l}\text { Hepatitis B status [No. } \\
(\%)]\end{array}$ & 0 & 0 \\
\hline $\begin{array}{l}\text { ARNVHC [No. }(\%)] \\
<600000 \mathrm{UI} \\
>600000 \mathrm{UI}\end{array}$ & $\begin{array}{l}3(50) \\
0\end{array}$ & $\begin{array}{l}3(50) \\
0\end{array}$ \\
\hline $\begin{array}{l}\text { Antiretroviral naïve [No. } \\
(\%)]\end{array}$ & 0 & 0 \\
\hline $\begin{array}{l}\text { HAART regimen [No. } \\
(\%)] \\
\text { RTV-boosted PI } \\
\text { NNRTI }\end{array}$ & $\begin{array}{l}3(50) \\
0\end{array}$ & $\begin{array}{l}3(50) \\
0\end{array}$ \\
\hline $\begin{array}{l}\text { Median age [years } \\
(\mathrm{IQR})]\end{array}$ & $\begin{array}{l}26.6(23- \\
33)\end{array}$ & $19.6(18-23)$ \\
\hline $\begin{array}{l}\text { Median CD4 cell count } \\
{[\text { cells } / \mu l(\mathrm{IQR})]}\end{array}$ & $\begin{array}{l}670(620- \\
710)\end{array}$ & $\begin{array}{l}360(285- \\
480)\end{array}$ \\
\hline HIV-RNA $<50 \mathrm{cop} / \mathrm{ml}$ & $3(50)$ & $3(50)$ \\
\hline $\begin{array}{l}\text { ASAT/ALAT > N [No. } \\
(\%)]\end{array}$ & $3(50)$ & $3(50)$ \\
\hline $\begin{array}{l}\text { Liver stiffness according } \\
\text { to Fibroscan }\end{array}$ & $\mathrm{F} 1 / \mathrm{F} 2$ & F3/F4 \\
\hline CDC clasification & $\mathrm{B} 1 / \mathrm{B} 2$ & $\mathrm{C} 1 / \mathrm{C} 2$ \\
\hline $\mathrm{Dg} \mathrm{HIV} / \mathrm{HCV}$ & $<10$ years & $>10$ years \\
\hline $\begin{array}{l}\text { ARVT Compliance/ } \\
\text { Adherence }\end{array}$ & $>90 \%$ & $<80 \%$ \\
\hline $\begin{array}{ll} & \text { Genotype 1b [No. } \\
(\%)] & \end{array}$ & $3(50)$ & $3(50)$ \\
\hline $\begin{array}{c}\text { Interleukin } \\
28[\text { No. }] \\
\mathrm{CC} \\
\mathrm{CT} \\
\mathrm{TT} \\
\end{array}$ & $\begin{array}{l}0 \\
3 \\
0\end{array}$ & $\begin{array}{l}0 \\
2 \\
1\end{array}$ \\
\hline
\end{tabular}


Table 2. Evolution of $H C V-R N A(U I / m l)$

\begin{tabular}{|l|c|c|l|l|l|l|l|}
\hline PT & \multicolumn{1}{|l|}{ Baseline } & wk4 & wk12 & wk24 & wk48 & wk72 & wk96 \\
\hline 1 & 156.321 & 43 & $\begin{array}{l}\text { UND } \\
\text { (undetectable) }\end{array}$ & UND & UND & UND & UND \\
\hline 2 & 109.328 & 55.031 & 496 & UND & UND & 3.210 & 12.520 \\
\hline 3 & 1.483 .213 & 243.669 & 4.252 & UND & UND & 103 & 753.000 \\
\hline 4 & 132.112 & 36.009 & 5.558 & 83.691 & & & \\
\hline 5 & 13.841 .230 & 28.466 .986 & 51.533 .380 & & & & \\
\hline 6 & 5.216 .590 & 1.261 .280 & 125.860 & & & & \\
\hline
\end{tabular}

All patients had antiviral treatment, which did not change during therapy with interferon and ribavirin: combivir + saquinavir/ritonavir - 2 patients, truvada + saquinavir/ritonavir -2 patients, truvada + kaletra- 1 patient, combivir + kaletra -1 patient

During therapy, CD4 decreased in all patients; HIV RNA remained undetectable for 48 weeks only for the first 2 patients. Detectable levels of HIV RNA were found at the 12 weeks for the rest of the patients.

The following adverse reactions have been reported: anaemia in six cases (a more pronounced anemia in Combivir containing regimens), leukopenia in two cases, thrombocytopenia in one case, weight loss( two cases), depression (one case), hair loss (one case) and cough (one case). In all 6 cases, therapy dosage for ribavirin was low. Every case with anemia and leukopenia, received complementary treatment with erythropoietin and respectively filgrastin.

SVR was achieved in $16.6 \%$ of cases (only one patient) and correlated with HCV RNA level, CD4 count, duration of HIV infection, CDC classification and liver fibrosis.

\section{Conclusion}

Our study group has a low prevalence of HIV / HCV co-infection (2.5\%) and a large number of patients $\mathrm{HCV} \mathrm{Ab}$ positive, but undetectable $\mathrm{HCV}$ RNA. One patient, representing $16,6 \%$ of cases, achieved sustained viral response, this percentage being lower than literature data. Positive predictive factors for SVR were: low levels of HCV RNA, small duration of the HIV infection, high levels of CD4, B1/ B2 (CDC classification) and low degree of fibrosis.

\section{Discussion}

HCV therapy in HIV infected patients encounters difficulties every time due to drug interactions and side effects. Several authors have published results more or less encouraging. The randomized, double-blind, international study in specialist outpatient clinics in the United States, Spain, and Portugal compares the efficacy and safety of 2 RBV dose regimens $(800 \mathrm{mg} /$ day and $1000 / 1200 \mathrm{mg} /$ day) combined with peginterferon alfa-2a in patients with HIV-HCV (genotype 1) coinfection. SVR rates were $19 \%(26 / 135)$ and $22 \%(60 / 275)$ in patients randomized to RBV $800 \mathrm{mg} /$ day and 1000/1200 mg/ day. The incidence of hemoglobin reductions $<10 \mathrm{mg} /$ $\mathrm{dL}$ were higher versus the standard $800 \mathrm{mg} /$ day RBV dose group [12]. Another study notes that pegylated interferon (peg-IFN) induced neutropenia in subjects coinfected with human immunodeficiency virus (HIV) and hepatitis C virus (HCV) is associated with increased risk of serious infections [13]. This happens due to a decrease in CD4 lymphocytes during therapy with pegylated interferon, which increases the risk of aquirring severe opportunistic infections. It was noted also that HIV reactivation occurs during therapy with 
peginterferon, despite the fact that patients were adherent and HAART was potent. This seems to have prevented and maintained SVR 6 months after therapy (at the 72 weeks mark). Maintaining low percentage of SVR may be due to Combivir regimen (which stressed the RBV-induced anemia).

The number of patients with undetectable HCV-RNA and HCVAb can be explained by the use of ritonavir (protease inhibitor), as part of a mandatory component of HAART. This is currently demonstrated by the use of antiviral therapy without interferon (ABT450, ABT267, ABT333) which associates ritonavir. Our case is the first case of HIV and HCV coinfection in Romania legally considered cured of $\mathrm{HCV}$.

\section{References}

1. Anderson, K.B., Guest, J.L. \& Rimland, D. (2004). Hepatitis C virus coinfection increases mortality in HIV-infected patients in the highly active antiretroviral therapy era: data from the HIV Atlanta VA Cohort Study. Clin Infect Dis. 39(10), 1507-1513. doi: 10.1086/425360

2. Alvarez, D., Dieterich, D.T., Brau, N., Moorehead, L., Ball, L. \& Sulkowski, M.S. (2006). Zidovudine use but not weight-based ribavirin dosing impacts anaemia during $\mathrm{HCV}$ treatment in HIV-infected persons. $J$ Viral Hepat. 13(10), 683-689. doi: 10.1111/j.13652893.2006.00749.x.

3. Bica, I., McGovern, B., Dhar, R., Stone, D., McGowan, K., Scheib, R. \& Snydman, D.R. (2001). Increasing mortality due to endstage liver disease in patients with human immunodeficiency virus infection. Clin Infect Dis. 32(3), 492-497. doi: 10.1086/318501.

4. Cohen, M.H., French, A.L., Benning, L., Kovacs, A., Anastos, K., Young, M., Minkoff, H. \& Hessol, N.A. (2002). Causes of death among women with human immunodeficiency virus infection in the era of combination antiretroviral therapy. Am J Med. 113(2), 91-98.

5. Fleischer, R., Boxwell, D. \& Sherman, K.E. (2004). Nucleoside analogues and mitochondrial toxicity. Clin Infect Dis. 38(8), e79-80. doi: 10.1086/383151.

6. Graham, C.S., Baden, L.R., Yu, E., Mrus, J.M., Carnie, J., Heeren, T. \& Koziel, M.J. (2001). Influence of human immunodeficiency virus infection on the course of hepatitis $\mathrm{C}$ virus infection: a meta-analysis. Clin Infect Dis. 33(4), 562-569. doi: 10.1086/321909.

7. Jacobson, I.M., McHutchison, J.G., Dusheiko, G., Di Bisceglie, A.M., Reddy, K.R., Bzowej, N.H., Marcellin, P., Muir, A.J., Ferenci, P., Flisiak, R., George, J., Rizzetto, M., Shouval, D., Sola, R., Terg, R.A., Yoshida, E.M., Adda, N., Bengtsson, L., Sankoh, A.J., Kieffer, T.L., George, S., Kauffman, R.S., Zeuzem, S. \& Team, A.S. (2011). Telaprevir for previously untreated chronic hepatitis $\mathrm{C}$ virus infection. $N$ Engl J Med. 364(25), 2405-2416. doi: 10.1056/ NEJMoa1012912

8. Laufer, N., Laguno, M., Perez, I., Cifuentes, C., Murillas, J., Vidal, F., Bonet, L., Veloso, S., Gatell, J.M. \& Mallolas, J. (2008). Abacavir does not influence the rate of virological response in HIV$\mathrm{HCV}$-coinfected patients treated with pegylated interferon and weight-adjusted ribavirin. Antivir Ther. 13(7), 953-957.

9. Martin-Carbonero, L., Soriano, V., Valencia, E., Garcia-Samaniego, J., Lopez, M. \& GonzalezLahoz, J. (2001). Increasing impact of chronic viral hepatitis on hospital admissions and mortality among HIV-infected patients. AIDS Res Hum Retroviruses. 17(16), 1467-1471. doi: 10.1089/08892220152644160.

10. Mira, J.A., Lopez-Cortes, L.F., Barreiro, P., Tural, C., Torres-Tortosa, M., de Los Santos Gil, I., Martin-Rico, P., Rios-Villegas, M.J., Hernandez-Burruezo, J.J., Merino, D., LopezRuz, M.A., Rivero, A., Munoz, L., GonzalezSerrano, M., Collado, A., Macias, J., Viciana, P., Soriano, V. \& Pineda, J.A. (2008). Efficacy of pegylated interferon plus ribavirin treatment in $\mathrm{HIV} /$ hepatitis $\mathrm{C}$ virus co-infected patients receiving abacavir plus lamivudine or tenofovir plus either lamivudine or emtricitabine as 
nucleoside analogue backbone. $J$ Antimicrob Chemother. 62(6), 1365-1373. doi: 10.1093/jac/ dkn420

11. Poordad, F., McCone, J., Jr., Bacon, B.R., Bruno, S., Manns, M.P., Sulkowski, M.S., Jacobson, I.M., Reddy, K.R., Goodman, Z.D., Boparai, N., DiNubile, M.J., Sniukiene, V., Brass, C.A., Albrecht, J.K., Bronowicki, J.P. \& Investigators, S.-. (2011). Boceprevir for untreated chronic HCV genotype 1 infection. $N$ Engl J Med. 364(13), 1195-1206. doi: 10.1056/NEJMoa1010494.

12. Rodriguez-Torres, M., Slim, J., Bhatti, L., Sterling, R., Sulkowski, M., Hassanein, T., Serrao, R., Sola, R., Bertasso, A., Passe \& Stancic, S. (2012). Peginterferon alfa-2a plus ribavirin for HIV-HCV genotype 1 coinfected patients: a randomized international trial. HIV Clin Trials. 13(3), 142-152. doi: 10.1310/hct1303-142.

13. Serrano-Villar, S., Quereda, C., Moreno, A., Perez-Elias, M.J., Casado, J.L., Royuela, A., Dronda, F., Navas, E., Hermida, J.M. \& Moreno,
S. (2013). Neutropenia during therapy with peginterferon and ribavirin in HIV-infected subjects with chronic hepatitis $\mathrm{C}$ and the risk of infections. Clin Infect Dis. 57(3), 458-464. doi: $10.1093 / \mathrm{cid} / \mathrm{cit} 221$

14. Tuma, P., Jarrin, I., Del Amo, J., Vispo, E., Medrano, J., Martin-Carbonero, L., Labarga, P., Barreiro, P. \& Soriano, V. (2010). Survival of HIV-infected patients with compensated liver cirrhosis. AIDS. 24(5), 745-753. doi: 10.1097/ QAD.0b013e3283366602.

15. Vispo, E., Barreiro, P., Pineda, J.A., Mira, J.A., Maida, I., Martin-Carbonero, L., RodriguezNovoa, S., Santos, I., Lopez-Cortes, L.F., Merino, D., Rivero, A. \& Soriano, V. (2008). Low response to pegylated interferon plus ribavirin in HIV-infected patients with chronic hepatitis $\mathrm{C}$ treated with abacavir. Antivir Ther. 13(3), 429-437. 